Taylor Nutter

University of Notre Dame

\title{
Metaphysics and the Existential Problematic of Human Finitude
}

Rather than being of little practical importance, the metaphysical underpinnings of a given horizon determine the character of its existential problematic. For instance, in the wake of Kant's a priori nominalism, Nietzsche considered the fundamental philosophical task of the post-metaphysical, post-moral West to be the construction of a new set of values that would avoid the despair that follows upon the nihilism which arises in the absence of objectively grounded values. With the breakdown of classical metaphysics concomitant with the modern turn to the subjective, the existential problematic of finitude as ultimate and encapsulating horizon arose. According to this subjective turn, the human person can no longer engage the world of experience and thought as though it were in itself constituted by transcendently grounded meaning and value. Such a dislocation from things-in-themselves makes for a finitude trapped within its own confines, unable to give credence to classical notions of being and truth as objective and absolute. Recognizing one's finitude, therefore, consists of recognizing such limitations. Whereas classical metaphysics once spoke of the divine as ultimate ground and ultimate end, contemporary thought must now courageously hold death/finitude in view as the definitive and defining limit condition for possible meaning and value.

It is the contention of this paper that Martin Heidegger stands within the trajectory of this genealogical lineage inasmuch as he makes the human person and her horizon the locus, and therefore finitude the limit condition, of the disclosure of Being whether as the 'there' (Dasein) of the 'world' in which entities are encountered or as belonging together with Being in Being's own revelation to and concealment from thought. While Heidegger's notion of being-in-theworld avoids the dislocation of the Kantian subject, his notion of 'world' and 'disclosure' as 
horizon nonetheless places meaning within a limit beyond which there is only 'nothing'. In contrast, while Bernard Lonergan S.J., does speak of the human person as self-transcendently open to being, and thus, in a sense, as a locus for the self-disclosure of being, he does not understand human finitude as an ultimate horizon enveloping one's possibilities for being. Rather, Lonergan keeps open the possibility, by way of grace, of true human self-transcendence toward a divine Being and Love that transcends all horizons. Both thinkers, then, conceive of authenticity in terms of the human person's relation to Being. As such, this paper will explore the impact one's conception of human finitude has on one's conception of authenticity by comparing and contrasting Heidegger and Lonergan's respective notions of authenticity as they relate to each their own respective analysis of the nature of metaphysics. This method is complexified by the fact that Heidegger's thought developed from asking about the meaning of Being by way of an analysis of human being-in-the-world to asking about Being itself in its own self-disclosure. It is my contention, however, that there is a continuity to be found between the early Heidegger's notion of the 'worldhood' of the world and the later Heidegger's notion of Being as the presencing or clearing which makes beings present to thought. In both cases, whether as 'anticipatory resoluteness' or as self-releasement to being appropriated by an event of Being, Heidegger's notion of authenticity intimates a persistent openness to the possibilities-for-being encapsulated within one's finite horizon. First, then, we must track this unity-in-development in Heidegger's thought before turning to Lonergan.

In Being and Time, Heidegger characterizes death as "that possibility which is one's ownmost, which is non-relational, and which is not to be outstripped ... Death is something 
distinctively impending". ${ }^{1}$ Just as we find ourselves thrown into a world of possibilities not of our own making, so too do we find death as an always impending possibility thrown on us without our choosing. Such 'thrownness' arouses in us an anxiety at the uncanniness of the prospect of the closure of our entire world. This anxiety arises from the impossibility of wholeness and the inability to be completely at home in the world because of our "primordial, thrown Being-in-the-world as the 'not-at-home' - the bare 'that-it-is' in the 'nothing' of the world". ${ }^{2}$ This 'nothing' stands at the bottom of the call of our conscience which convicts us of being guilty with a guilt that is not the traditional cognizance of one's sinfulness, but the foundational Nichtigkeit ('nullity') of life and its attendant possibilities in the light of the ultimate finality of death: "The 'nothing' with which anxiety brings us face to face, unveils the nullity by which Dasein, in its very basis, is defined; and this basis itself is as thrownness into death". As the limits of the world into which one finds oneself thrown are the limits of one's possibilities for being, and as the human person just is such a potentiality-for-Being, death annihilates one's being in its entirety as the definitive closure of one's world. Accordingly, Heidegger contrasts authenticity with the existential comportment of 'the they', or the unreflective masses who flee from the reality of the possibility of the definitive closure of one's world, seeking the comfortable confines of the familiar: "The 'they' knows only the 'general situation', loses itself in those 'opportunities' which are closest to it". ${ }^{4}$ In contrast to this, the authentic anticipation of death brings the human person to "an impassioned freedom toward death - a freedom which has been released from the Illusions of the 'they', and which is factical,

${ }^{1}$ Martin Heidegger, Being and Time, trans. John Macquarrie and Edward Robinson (New York: Harper and Row, 1962), 294/251.

${ }^{2}$ Ibid., $321 / 276$.

${ }^{3}$ Ibid., 356/308.

${ }^{4}$ Ibid., 346/300. 
certain of itself, and anxious". This anticipation "utterly individualizes Dasein, and allows it, in this individualization of itself, to become certain of the totality of its potentiality-for-Being". 6 When one anticipates one's death, the only way to do so authentically is to resolve oneself not to hide oneself from it in 'the they'. Death frees one to live in the totality of actual possibilities of a finite horizon. Authenticity, for the early Heidegger, consists of an 'anticipatory resoluteness' in the face of that anxiety which results from the definitive nullity of one's possibilities in the light of the absolute finality of death.

One can hear in the individualism of the early Heidegger's formulation of authenticity as 'anticipatory resoluteness' a hint of the influence of Nietzsche and Kierkegaard. It was from such an individualism and a focus on the subject that the later Heidegger turned. Nevertheless, in both his earlier and later thought, Heidegger took finitude to be the limit condition for meaning, the definitive limit of one's horizon. In The Onto-Theo-Logical Constitution of Metaphysics, Heidegger expounds on the 'ontological difference' between Being and beings as determining any and all metaphysical formulations, including those about God. Taking his starting point from the dialectic of Hegel's logic, Heidegger notes that metaphysics by nature determines beings in and through the mutual determination of what is in the deepest sense, the Highest Being or God (as corresponding to theology), and what is most generally, the empty minimum of all that is (as corresponding to ontology): "Being grounds beings, and beings, as what is most of all, account for Being". 7 Even God must answer to the dialectic of this most fundamental ontological difference. Living only within this dialectical relationship, metaphysics forgets its own primordial 'whence' in the difference as such. Thus, Heidegger seeks to move beyond the

${ }^{5}$ Ibid., $311 / 266$.

${ }^{6}$ Ibid., 310/266.

${ }^{7}$ Martin Heidegger, Identity and Difference, trans. Joan Stambaugh (Chicago: University of Chicago Press, 1969), 69. 
formulaic restrictions of metaphysics into a contemplation of Being itself in its 'clearing' as the "openness that grants a possible letting appear". ${ }^{8}$ This clearing is always historic and epochal and, therefore, finite. ${ }^{9}$ Every manifestation epochally cleared finds its limit and determination in the 'nothing' which does not show itself. No one clearing can disclose the definitive formulation of 'what there is' because it conceals just as it unconceals. ${ }^{10}$ It is the task of the authentic person to give herself over to this finite 'clearing', to let it manifest itself of its own accord, to be appropriated by it. In doing so one gives thanks for thought as Being gifts itself over to it.

Comparing Lonergan and Heidegger, Paul Kidder once wrote that authenticity "in Lonergan, is typically characterized in terms of fidelity to norms of conscious intentionality rather than in terms of an appropriation of the groundless ground of the disclosure of being". ${ }^{11}$ Though part of a critique of Lonergan, this can perhaps be used instead as an indictment of Heidegger. That is, while responding to William J. Richardson's Heideggerian critique of him, Lonergan reasserted the primacy of cognitional theory as setting the foundation for the formulation of any metaphysics: "Basically it is a matter of deriving basic terms and relations from the data of consciousness, of accepting traditional metaphysics in the sense that is isomorphic with these basic terms and relations". ${ }^{12}$ For the early Heidegger, "that Being-in-theworld which is constitutive for Dasein"13 is "the 'subjective' a priori" ${ }^{\text {"14 }}$ in which the human person always already finds herself enclosed as the totality of possibilities-for-Being. This

${ }^{8}$ Martin Heidegger, "The End of Philosophy and the Task of Thinking," in Basic Writings, ed. David Farrell Krell (New York: Harper and Row, 1993), 441.

${ }^{9}$ Martin Heidegger, Identity and Difference, 67.

${ }^{10}$ Ibid., 65.

${ }^{11}$ Paul Kidder, "The Lonergan-Heidegger Difference," in Philosophy and Theology 15, no. 2 (2003): 273-298. 282.

${ }^{12}$ William J. Richardson, "Being for Lonergan: A Heideggerean View," in Language Truth and Meaning, ed. Philip McShane (Notre Dame: University of Notre Dame Press, 1972), 312.

${ }^{13}$ Martin Heidegger, Being and Time 146/111.

${ }^{14}$ Ibid., 144/110. 
'apriority' then becomes, for the late Heidegger, the clearing/disclosure of Being of the specific historical epoch in which one finds oneself. In both cases, Heidegger makes this finite a priori constitutive of the horizon of the human person, thus not allowing for the possibility of openness to a truly transcendent divine. For Lonergan, in contrast, insights are a priori simply in that they "go beyond what is merely given to sense or to empirical consciousness". ${ }^{15}$ Heidegger can perhaps, therefore, be convicted of what Lonergan calls 'conceptualism', a forgetfulness of the subject in her conscious operations. ${ }^{16}$ In this way, then, Kidder was right to pinpoint the main difference between Lonergan and Heidegger in that while the former attends to the norms of conscious intentionality, the latter leaps into what appears to be the groundless ground of Being in the absence of any thoroughgoing cognitional theory. While Heidegger speaks of Being in terms of Dasein's Being-in-the-world or as being appropriated by an event of Being, Lonergan defines being as "the objective of the pure desire to know" ${ }^{17}$ While Heidegger understands beings as determined by the limits of the 'world' or by the 'ontological difference' of a specific epochal clearing, Lonergan speaks of the pure desire to know as unrestricted, a wonder which reaches to the very depths of the mystery of the real. By making insights, with their attendant heuristic anticipations and canons of method, the a priori of human conscious intentionality, rather than the 'world' or a specific 'clearing', Lonergan opens the possibility for true human transcendence toward the divine, for a life lived in the light of transcendently grounded meanings and values. Such meanings and values are not swallowed whole by the specter of finitude and death, nor determined by them.

${ }^{15}$ Bernard Lonergan, S.J., Insight: A Study of Human Understanding (Toronto: University of Toronto Press, 2013), 5.

${ }^{16}$ Bernard Lonergan, S.J., "The Subject," in A Second Collection, eds. Robert M. Doran and John D. Dadosky (Toronto: University of Toronto Press, 2016) 64.

${ }^{17}$ Bernard Lonergan, Insight, 372. 
As such, for Lonergan, "human authenticity is a matter of following the built-in law of the human spirit ... is a matter of achieving self-transcendence". ${ }^{18}$ We self-transcend in knowing and loving when we are attentive in experience, intelligent in inquiry, reasonable in judging, and responsible in deliberation. ${ }^{19}$ Openness to being results from intellectual probity, which in turn results in objectivity. Lonergan, therefore, asserts "that objectivity is the fruit of authentic subjectivity". ${ }^{20}$ But, openness is threefold: as fact, achievement, and gift. ${ }^{21}$ As fact, openness is the pure desire to know. As achievement, it "arises when the actual orientation of consciousness coincides with the exigencies of the pure, detached, disinterested, unrestricted desire to know." ${ }^{22}$ Lastly, as there is the possibility of following the exigencies of the desire to know from below upwards, from attentiveness through intelligence to reasonableness and responsibility, so there is the grace of God which speaks in our hearts as unbounded love, beckoning us to authenticity. This is openness as gift, "as an effect of grace...not as merely sanans but as elevans, as lumen gloriae" as "the self entering into personal relationship with God." ${ }^{23}$ Such a call to authenticity comes not from a reified present-at-hand something, nor from the call of Dasein's conscience to itself reminding itself of its guilt and nullity, but from the transcendent source of all that is, not limited to a particular horizon or the dialectic of a primordially given 'ontological difference'. Lonergan places this call at the center of the existential problematic, at the center of the problem of distancing oneself from 'the they', as Heidegger would put it. For Lonergan,

${ }^{18}$ Bernard Lonergan, S.J., "The Response of the Jesuit as Priest and Apostle in the Modern World," in A Second Collection, eds. Robert M. Doran and John D. Dadosky (Toronto: University of Toronto Press, 2016), 144.

${ }^{19}$ Bernard Lonergan, S.J., "Lectures on Religious Studies and Theology," in A Third Collection, ed. Frederick E. Crowe, S.J., (New York: Paulist Press, 1985), 144.

${ }^{20}$ Ibid.

${ }^{21}$ Bernard Lonergan S.J., “Openness and Religious Experience,” in Collection, eds. Frederick E. Crowe and Robert M. Doran (Toronto: University of Toronto Press, 2015), 186.

${ }^{22}$ Ibid.

${ }^{23}$ Ibid., 187. 
Out of that company of drifters one steps when one faces the problem of personal existence, that is, when one finds out for oneself that one has to decide for oneself what one is to do with oneself, with one's life, with one's five talents or two or lonely one. Commonly such a discovery, such a decision, such a program of self-transcendence becomes effective and irrevocable when one falls in love. ${ }^{24}$

So it is that just "as a total openness to all questioning is our capacity for self-transcendence, so too an unrestricted being in love is the proper fulfilment of that capacity." ${ }^{25}$ Lonergan identifies this love as "God's love flooding our hearts through the Holy Spirit given to us" from Romans 5:5. ${ }^{26}$ God's love, then, becomes the principle of our self-transcendence and, therefore, of our living authentically. It "bears fruit in acts of love for one's neighbor, a love that strives mightily to bring about the kingdom of God on earth." 27 As coming from God it "is not the product of our knowledge and choice"; rather "it dismantles and abolishes the horizon within which our knowing and choosing went on, and it sets up a new horizon within which the love of God transvalues our values and the eyes of that love transform our knowing." ${ }^{28}$ Authenticity as provoked by the love of God moves us beyond ourselves and our small world with a hope that neither disappoints nor is naïve. Such love has refashioned death into a birth unto new life in the hope of the resurrection. Our finitude, as elevated by grace, cannot be confined to its own fallen, or even natural, limits. In the context of a concrete life of holiness in the here and now, we are lifted upward to an ever greater union with that love which grounds all things, to an authenticity which is open to Being and Love in its transcendence of all horizons.

${ }^{24}$ Bernard Lonergan, "Lectures on Religious Studies and Theology," 123.

${ }^{25}$ Bernard Lonergan, "The Response of the Jesuit as Priest and Apostle in the Modern World," 145.

26 Ibid.

${ }^{27}$ Ibid.

${ }^{28}$ Ibid., 145-146. 